\title{
Right-wing Extremism and No-go-areas in Germany
}

\author{
LUKÁŠ NOVOTNÝ \\ Jan Amos Komenský University, Prague
}

\begin{abstract}
Right-wing extremist groups in almost every Western European country became aware of the concept of no-go-areas over the course of the 1980s and 1990s, and some of them even applied this concept over a short period. This study looks at the manifestations of this concept in Germany, where politics and society are still confronted with the legacy of Nazism. The author sets out to examine whether no-go-areas actually exist in Germany, and if they do, to look at how life in them is organised, how they are accepted by majority society, and how these activities are supported (or initiated) by the NPD, a German right-wing extremist party. In the region of former East Germany in particular there has been an increase in support for neo-Nazism as an extreme reaction to the deteriorating economic and social situation. Studies have shown that in this region more and more citizens are sinking into the 'modernisation trap', and as a result right-wing extremism and neo-Nazism are gaining more and more ground. One way in which the extreme right-wing NPD and related or subordinate 'friendly' organisations want to 'control the streets', and thereby also the public, is through the establishment of 'no-goareas', which are areas dominated by neo-Nazis. The objective is to create a zone for neo-Nazi sympathisers, chase out foreigners and co-citizens who do not share extremist views, and work towards achieving the ultimate goal: destroying democracy and establishing the 'Fourth Reich'.
\end{abstract}

Keywords: right-wing extremism, nationalism, racism, no-go-area, Germany Sociologický časopis/Czech Sociological Review, 2009, Vol. 45, No. 3: 591-609

\section{Introduction}

In May 2007, the interior minister of Saxony, Albrecht Buttolo, banned the extreme right-wing group 'Sturm 34'. The reason for his decision was the fact that members of Sturm were promoting the ideas of Nazism and were trying to establish so-called 'national liberated zones'(National befreite Zonen) in the Saxon town of Mittweida, and moreover doing so by unconstitutional means (Die Welt, 26 April 2007) [Verfassungsschutzbericht 2006: 65]. In the view of right-wing extremists, national liberated zones (no-go-areas) are areas in which the only figures of rule or the enforcement of order are right-wing extremists (usually neo-Nazis). They are zones to which foreigners have limited (or no) access. This was one of the objec-

* Direct all correspondence to: Lukáš Novotný, Department of Human Resources Development and the European Union, Jan Amos Komenský University in Prague, Roháčova 63, Prague, 130 00, Czech Republic, e-mail: novotny.lukas@ujak.cz.

(C) Sociologický ústav AV ČR, v.v.i., Praha 2009 
tives behind Sturm's objective to establish a 'national liberated zone' in Mittweida. In addition, some leaders in this organisation committed racially motivated violent crimes. At the time it was banned, the hard core of 'Sturm 34' was made up of twenty-five people [Walter 1994; Findeisen and Karsten 1999].

A no-go-area originates when representatives of extreme right-wing groups in a given location pressure the relevant national, metropolitan, and public authorities to relinquish 'supreme authority' over particular areas, such as playgrounds, discos, or entire sections of a town, the objective being to make these areas 'national liberated zones' or, in other words, oases for neo-Nazis. ${ }^{1}$ The extremists have a clear idea of what should be done with such areas: they should be made into areas where there are no foreigners (ausländerfrei), no Jews (judenfrei), and no democracy [Scherr 2007].

In this article, I will examine these no-go-areas, which are a very interesting but as yet unexplored aspect of political and social developments in German society. They were the subject of debate during the 2006 Football World Cup, when the African Council in Germany decided to draw up a special list of venues that visitors from African states should avoid. In fact, one-fifth of all racially motivated crimes committed by right-wing extremists in Germany in 2006 were committed against Africans or people of African descent. ${ }^{2}$ Places that the African Council recommended that Africans avoid included, for instance, the Berlin train station in Schöneweide, the neighbourhood of Köpenick, and the HellersdorfMarzehn and Lichtenberg areas of Berlin. In 2006, references to no-go-areas have even appeared in two English guidebooks: The Rough Guide to Berlin and Time out Berlin (Berliner Morgenpost, 3 May 2006).

Below I will begin by defining the nature and specific features of political extremism in Germany and then proceed to present the historical context behind the origins of these zones and examples of their existence in other countries. In order just to describe what the zones are, it was necessary to study the rightwing extremist press, in particular Deutsche Stimme, the magazine of the National Democratic German Party (Nationaldemokratische Partei Deutschlands; the NPD), Vorderste Front, the magazine of the Young National Democrats (Junge Nationaldemokraten), and other relevant sources. That discussion is followed by an analysis of the relationship of the strongest right-wing extremist political party the NPD, which evolved out of the post-war course of development of right-wing extremism in western Europe [von Beyme 1988], to these zones and to those who seek to establish them. In the closing part of the article I will outline the possible future of these zones and right-wing extremism in Germany.

\footnotetext{
${ }^{1}$ By neo-Nazism, I am referring, like C. Mudde, to an ideology that freely promotes the return of Hitler's Third Reich and/or which cites national socialism as their ideological origin [Mudde 2000: 230].

${ }^{2}$ http://www.afrikanet.info/index.php?option=com_content\&task=view\&id=829\&Item $\mathrm{id}=2$.
} 


\section{Conceptualising no-go-areas in the context of research on extremism}

\section{Right-wing extremism}

There are many definitions of political extremism. Jan Chmelík describes it concisely as the 'deviation from generally established and currently accepted standards. It takes the form of a political plan with strong components of opinion intolerance and the rejection of compromise solutions. It is manifested as a radical or even militant rejection of the politics of the state and the constitutional order, even by violent means' [Chmelík 2001: 7 an.]. Some authors, mainly those from Germany, insist on including anti-system attitudes or opposition to democracy as essential definitional criteria [Backes and Jesse 1989; Ignazi 2003; Wagner 1994]. According to this logic, which is shared by Germany's Federal Office for the Protection of the Constitution, democratic parties are parties that work to maintain the present democratic system or would like to establish such a system. Extremist parties are ones that according to general conceptions deviate from generally accepted and actually adopted democratic norms and strive to create or reinforce authoritarian or totalitarian dictatorship. Extremists consider themselves the only power that can 'rightly' take control and assert the interests of society [Hafeneger 1995: 42].

Right-wing extremism thus involves political entities that are trying to establish a racially, ethnically, and culturally uniform community. Typical attributes of right-wing extremism are that they are authoritarian, hierarchical, systemic, traditional, nationalistic, and play on the notion of duty [Stöss 2000: 25]. Right-wing extremists are a priori intolerant. They regard themselves as the conveyors of truth. They divide their neighbourhood into friends and enemies (Freund-FeindDenken), and their main enemy is the current political system - democracy and its representatives - which they consider decadent and corrupt, and all national, religious or other minorities, foreigners, and other groups [Bobbio 2003: 59]. In this way, right-wing extremists reject political equality and equality of protection under the law and nominate themselves as the ones who will create a political system that would establish human inequality and accord basic human rights and liberty in society unevenly among different groups of people according to ethnicity, race, and religion. Members of extremist groups regard each other as friends (Kameraden), while everyone else in their eyes are 'parasites' or 'leeches' (Zecken) [Helsing and Mahler 2001: 10; Verfassungsschutzbericht 2006: 65].

The German political scientists Uwe Backes and Eckhard Jesse [1989] distinguish four different types of right-wing extremism: first, extremism that uses violence and does not possesses a strong system; second, extremism that uses violence but embodies a strong system; third, extremism that does not use violence and is not organised; and fourth, extremism that does not use violence, but is very well organised. All these groups are represented in Germany. The most visible extremist groups nowadays are political parties, which have been experiencing a 'renaissance' in recent years, especially in Eastern Europe. The NPD is 
the most successful party so far and holds seats in the municipal legislature in Saxony, Mecklenburg-Vorpommern [Gertoberens 2004; Novotný 2008a]. About two thousand members of the NPD are estimated as having a primarily neo-Nazi orientation (out of a total of seven thousand NPD members; the party newspaper Deutsche Stimme has a print run of 21 000) [Novotný 2008b: 18].

\section{Extremism and modernity}

Although the NPD is without question the best-known and most successful rightwing extremist party, other forms of right-wing parties, non-party right-wing extremism, and right-wing movements and sub-cultures have also been making major progress. In 1992 the German political scientist Hans-Gerd Jaschke questioned whether perhaps right-wing extremism was turning into a new form of social movement [Jaschke 1994], and he noted that, particularly with respect to the new priorities of right-wing extremists, specifically, their ethnicisation of social and political issues, a new sub-culture is emerging that is capable of appealing to protest voters. This opinion evoked a wave of critical but also concurring responses [Rucht 2002; Hellmann and Koopmans 1998]. Today it is clear that Jaschke assessed the situation correctly. German extremists - especially the NPD - see their biggest objective as 'marching in the midst of the common people' (Marsch in die Mitte des Volkes) [Verfassungsschutzbericht 2006: 75]. According to various polls and surveys conducted in Germany, up to $15 \%$ of Germans sympathise with right-wing extremist views [Grumke 2007]. This modern extremism is the result of reactions of disadvantaged groups to 'the other modernity' [Minkenberg and Perrineau 2007]. For Ulrich Beck, characteristic of today is the widespread sense of a loss of security and safety [Beck 2004]. This is one of the reasons why more recent publications on right-wing extremism in Germany have emphasised social issues and the fact that extremism (both right- and left-wing) emerges in society when people's living standards and outlook in life deteriorate [Bergmann and Erb 1994; Klärner and Kohlstruck 2006].

Ronald Inglehart [1997] sees the decisive moment in the change of behavioural standards as the transition to 'post-material values'. This is what the German political scientists Erwin Scheuch and Hans-Dieter Kligemann were speaking about in the 1960s when they were assessing the causes of right-wing extremist party benefits, in particular those of the Republicans and the NPD. For Scheuch and Klingemann, this marked a change in voting behaviour towards the 'normal pathology of western industrial society' [Scheuch and Klingemann 1967: 12]. A concomitant effect was the attempt to ethnicise social issues by arguing that foreigners are at the root of the socio-economic problems Germany faces today. Right-wing extremists then try to put themselves in the role of the 'avengers', those who are trying to homogenise German ethnic and social sub-cultures.

The number of neo-Nazis, one of the most radical and anti-democratic groups in the spectrum of right-wing extremism, has been increasing in Germa- 
ny. According to the most recent news reports on constitutional order protection, the years 2006 and 2007 saw an increase in membership of about two hundred more people [Verfassungsschutzbericht 2007].

If we analyse the profile of current members of right-wing extremist groups, they are mostly socially deprived people. This suggests that voters of the NPD are mainly seeking an improvement in their social situation, and in this respect they favour the displacement of foreigners and minorities and even limiting their rights and freedoms. A number of studies from German public opinion institutes (for example, a study by Forsa conducted in August 2007 on a sample of the German population) showed that about $2 \%$ of the German population support the NPD (and another right-wing extreme party DVU) and $4 \%$ of the German public can imagine that one day they could vote for a right-wing extremist party, while another $7 \%$ would vote for them under certain circumstances (Der Spiegel, $23 \mathrm{Au}-$ gust 2007). Among the unemployed support for right-wing extremist parties is twice as high as in the general public. In addition, according to the above-mentioned study by Forsa, up to one-quarter of the unemployed are able to imagine that they could vote for such a party. In terms of the support for right-wing extremist parties, a negligible (and statistically immeasurable) minority of the right-wing extremist intelligentsia is oriented towards nationalism and chauvinism (völkisch ideologies). Among roughly one-half of these older sympathisers and voters, there is evident interest in a return to 'old times', that is, going back to National Socialism.

The younger generation is different. Young right-wing extremists are trying to find another 'way of life'. They are familiar with one old rule: the years between the ages of 12 and 16 are of crucial significance for shaping their political opinions. The presidium of the German extremist NPD, headed by Udo Voigt, wrote about this in one of the party's most recent documents. That is why we are now witnessing a massive offensive from the NPD to target this age group. ${ }^{3}$ Today there are about one thousand extremist web sites in German [Novotný 2008b: 18]. They provide visitors with information about the actions of different movements and about where to buy music CDs by neo-Nazis groups, t-shirts, jackets, and brand (Thor Steinar) items bearing neo-Nazis symbols, such as Celtic crosses, black suns, or the number 28 , which symbolises the letters $B$ and $H$, signifying the group Blood and Honour, that since 2000 has been banned in Germany [Virchow 2004].

Current results from different studies conducted among students in Germany reveal some unpleasant findings: for example, research among high-school students between the ages of 13 and 19 conducted in 2003 in Hagen in the Rheinland (on a sample of 676 students) indicated that $46 \%$ of them agree with the opinion that foreigners living in Germany should adapt more to the lifestyle of Germans.

\footnotetext{
${ }^{3}$ According to research by ARD/Infratest, 17\% of all voters between the ages of 18 and 24 voted for the NPD in Mecklenburg-Vorpommern. Among men in this age group the NPD even gained as much support as the SPD [Verfassungsschutzbericht 2006: 92].
} 
One-third of those interviewed believed that foreigners are a priori more inclined towards criminality than Germans, 30\% said they feel like foreigners in their own country, 20\% would not allow any foreigners into Germany, and $11 \%$ think that Jews in Germany should have fewer rights than Germans. Claus Homm, the author of the study, concluded that roughly $11.5 \%$ of these pupils are xenophobic and have a tendency to support neo-Nazism. Boys and young men show more sympathy for these views than girls and women. Homm suggests immediately strengthening education in democracy and in tolerance before right-wing extremists gain greater influence on shaping the political opinions of these young people.

\section{No-go-areas}

The notion of 'national liberated zones' (no-go-areas) has appeared in the discourse of right-wing extremist groups in Germany since the 1990s [Wagner 1998]. These zones were first mentioned in Germany in articles published in magazines, like Einheit und Kampf (no. 2, September 1990) and Vorderste Front (1991); [Jaschke and Rätsch 2001: 119], and in the magazines of the National-Democratic University Union (Nationaldemokratischer Hochschulbund) and the Young National Democrats (Junge Nationaldemokraten), a student organisation of the NPD. According to a main article in Einheit und Kampf, titled 'Make National Liberated Zones' (Schafft national befreite Zonen), it is the objective of right-wing extremists to take control of different parts of towns, such as discos, bars, public squares, and other (for them) important public places. Attempts to take control of these places have so far always been accompanied by violence against those parts of the public that extremists view as a problem. Reading these and other extremist texts about nogo-zones (they will be mentioned below) evokes an association with the period of National Socialism, when Nazis battled to establish 'Jew-free' zones ('judenfreie' or 'judenreine Gaue'). There is no doubt that creating such a situation is the objective of the 'zone' initiators today.

Einheit und Kampf, mentioned above, pointed out the economic and territorial independence of these zones. Economic independence from the state is important to extremists because such independence would enable them to break free from what they call financial capitalism. It would allow extremists financial freedom and opportunities to obtain financing from their activities (for example selling CDs, brand clothes, posters, flags, etc.). Neo-Nazis want to be the sole subculture to exercise authority in these 'zones', assume a self-governing function, and pursue political and cultural activities in these zones [Geyer 2002: 98].

They have been particularly successful in the newest federal state - the former territory of the GDR. In this region young people in particular are losing 'the self-confidence of current existence' owing to the unmet promises of modernisation and the poor socio-cultural conditions that offer no perspectives to young people [Bauman 2003: 156]. These young people often fall into the 'social 
trap' or 'modernisation trap', as defined by Klaus Wahl in the late 1980s [Wahl 1989; Milza 2005], where by escaping into extremist sub-cultures these young people are seeking safety and security. Richard Sennet describes the situation by noting that there is a defensive element to the longing to belong to a community, wherein the community of 'us' can be employed anywhere and anytime in defence against chaos and oppression [Sennett 1998: 138]. These kinds of socially excluded can limit their social competences, especially in relation to co-existence with groups that are easy to blame as the cause of the deterioration in their social situation, groups like minorities and foreigners. This outlook can then progress quickly to an aggressively xenophobic stage. A good illustration of this is the formation of no-go-areas and the desire to be the only source of 'law and order' in such zones. By establishing these zones, those behind them achieve a substitute form of what others - socialised in democratic values and society - achieve in their everyday lives, that is, social recognition, assuming that social and welfare recognition is a normative condition of all communicative behaviour.

The intention behind the creation of no-go-areas is to create a counterweight to existing state institutions that otherwise control a given area. By establishing these zones right-wing extremists also aim to establish contact with the rest of the population, providing people with assistance and offering economic and social alternatives (Einheit und Kampf 1990: 52). In those areas that neo-Nazis designate as no-go-areas they mark the public spaces with various, typical Nazigroup symbols, such as ' $88^{\prime}$ ' or 'NBZ' - the abbreviation for the 'national liberation zone'. Such areas tend to be urban neighbourhoods or residential areas that have socio-economic problems and high crime rates (for example, MagdenburgOlvenstedt and Guben). ${ }^{4}$

It is hard to determine how many of these zones exist. The Office for the Protection of the Constitutional Order in the federal state of Brandenburg registers 17, but does not consider them (as I have said) to be 'national liberation zones', the way the right-wing extremists do, but thinks of to them as 'fear zones' (Frankfurter Rundschau, 26 February 1997). The Federal Office for the Protection of the Constitution and many research studies [Döring 2008] are implying that these zones do not yet exist in Germany and remain an (as yet) unfulfilled objective of various right-wing extremist subjects, mainly the NPD. The 17 zones cited in the 2007 annual report of Brandenberg's Office for the Protection of the Constitutional Order are zones where extremists have managed to cut out all other groups from participating in social life, or more precisely, they have excluded

\footnotetext{
${ }^{4}$ Statistics on criminal offences provide information about which neighbourhoods are being affected. For example, in Magdeburg most crimes were committed in Olvenstedt and Wolmirstedt, in Schwerin in Hagen, in Halle in Südstadt, and in Merseburg. Olvenstedt is a very rundown neighbourhood. In 1993 it experience a population increase of just one inhabitant, followed by a steep decrease in inhabitants in subsequent years. Between years 1990 and 2000 there was a decrease of 39\%. The biggest decreases in the number of inhabitants occurred between 1996 and 2000 [Döring 2008: 197].
} 
other (non-neo-Nazi) groups from participating in or attending any cultural or other activities, such as youth clubs, rock clubs, pubs, etc.). In doing so, they have been able to establish something like a 'third position' between capitalism and communism. Torald Staud speaks of the gradual Fascisation of some places and remarks: 'National liberation zones don't exist here, but there are such places where there are very few governable democratic parties' [Staud 2006: 10; Niethammer 1969]. These places are becoming real 'fear zones' and, considering the behaviour of some groups, are to be avoided.

\section{No-go-areas in Germany}

The German notion of 'no-go-areas' is influenced by the Western European experience of right-wing extremism (mostly neo-Nazi) groups, where there have been discussions about establishing these 'zones' since the 1980s [Glyn 1992]. However, the earliest remarks in the German periodicals Einheit und Kampf and Vorderste Front support, with the backing of the British neo-Nazi movement, the 'International Third Position'. One model of this was developed by right-wing extremists in the Italian group Terza Posizione (TP), which managed to establish some degree of economic and political infrastructure in the form of several shops, cultural centres, and self-schooling for children of working Italians (mainly farmers). In this way the TP offered the working classes an alternative to 'normal life' and halted the progress of the Communist Italian Party (KPI) [Döring 2008: 56]. Alongside the Terza Posizione that emerged in the mid-1980s, there was the Spanish group Bases Autonómas (BA), which attempted to create a system of no-goareas, the Portuguese Movimento de Accao National (MAN) (Einheit und Kampf 1/1990: 34); [European Monitoring Centre 1999: 34], and the French Nouvelle Résistance [Bale 2002: 36]. The German right-wing extremist press evaluated the actions of these groups in glowing terms as exemplary progress.

After German right-wing extremists discovered the concept of no-go-areas at the start of the 1990s, their operations and programme aims showed no evidence of their having developed this model further in some way. A change came in the mid-1990s with the emergence of the internet network 'Thule', a kind of vox populi of right-wing extremists on the internet, uniting like-minded groups throughout Germany [Dietzsch and Maegerle 1996: 924]. Thule-Journal explains the objective of the network's initiators: 'With the help of networking mailboxes we want to create a free zone' (Thule-Journal 1/1993: 3). Activity on Thule grew rapidly after it was set up, and there were even discussions on the network of nogo-areas. In March 1997 the sites died out, apparently owing to internal disagreement among their founders [Dietzsch and Maegerle 1997: 178; Verfassungsschutzbericht 1998: 79]. After Thule's extinction, discussion about no-go-areas vanished from Germany for several years. It resurfaced at the end of the 1990s, mainly in neo-Nazi organisations in Saxony, such as Nationaler Jugendblock Zittau or Junges Nationales Spektrum [Verfassungsschutzbericht Sachsen 2003: 13]. 
The concept of no-go-areas, according to right-wing extremists, is based on several criteria. First, a no-go-area should lead to the creation of 'national centres' (Deutsche Stimme 11/1999: 18). However, how this is achieved is not entirely clear from the articles in the right-wing press. One of the ways envisioned is by right-wingers buying up land and real estate in specific parts of a neighbourhood, where everybody who embraces German nationalism can conduct their lives freely. This approach is of course unrealistic given the low socio-economic status of right-wing extremists today. However, Steffen Hupka, the author of an article published in Deutsche Stimme, considers this a realistic aim and believes that it 'is possible to collect the necessary money with the help of friends who are employed' (author's translation; Deutsche Stimme 11/1999: 18). He also imagines that in such a zone right-wing extremists would then be able to create their own infrastructure, separate from the state, and in their zone they could collect rent, provide loans, manage the buildings, organise concerts, own stores, etc. According to him, these centres would become 'national fronts' [Röpke 2004].

Second, in order to establish such a system of national centres it is necessary to increase the membership level of right-wing extremist associations and political parties. Increased activity at the federal level should help to achieve this. Members of friendly groups and other associations are, for example, encouraged to take part in various existing organisations. It is regarded as a success if by this means someone manages to gain as many new backers as possible and is able to take over the group's decision-making and thus essentially 'dislodge' their entire operation (Deutsche Stimme 1/2000: 18). In it in these 'grey zones', for example, in organisations of exiles, student groups, or other revisionist, friendly 'associations', Neo-Nazis see an opportunity to assert and create a 'bridge to civil society' (Deutsche Stimme 5/2000: 16). The main objective is to get close to the ordinary people and take up as their own the themes that are most important to those people; for example, themes like the fight against environmental pollution or for animal protection, against abortion, unemployment, etc. (Deutsche Stimme 1/2000: 18). In addition, neo-Nazis also retain their 'traditional' themes, where they have already secured some achievements, primarily in the above-mentioned 'grey zones'. One such theme is a revisionist view of the Second World War or the conviction that 'Germany is bigger then the Federal Republic', whereby they are referring to the lost, formerly German eastern regions that were inhabited by German minorities [Staud 2006: 17].

Third, to establish no-go-areas right-wing extremists bet on eliminating 'deep-seated defence reflexes' (Deutsche Stimme 2/2002: 17; 4/2002: 7), by which they mean 'liberating' Germans from the Nazi past, 'from the psychological pressure of the spirit of the time' (Deutsche Stimme 3/2000: 22), and thus to rid them of their constant self-consciousness of ritually apologising for their history. In their view, this is all a part of political correctness, which in the right-wing extremist press is referred to as 'Unsinn' or nonsense (Deutsche Stimme 2/2002: 3). The NPD and its 'struggle for minds' is ascribed a big role in achieving this aim. 
Fourth, by establishing no-go-areas it is necessary to strengthen the 'organised will' of the youth and offer them sufficient options for self-fulfilment while at the same time endeavouring to unify the opinions of and discipline the youth (Deutsche Stimme 2/1999: 11; 10/1999: 17; 12/1999: 14). This is succeeding well particularly in the east of Germany, where even many years after the fall of communism the establishment of a communal, embedded, civil society failed (for example, churches and unions in this part of the country have few members than in the western part of Germany) and right-wing extremists here have begun to win support, especially among disillusioned youth.

\section{Right-wing extremists and control over locations}

Uta Döring distinguishes between public, semi-public, and private places where right-wing extremists attempt to establish NGAs [Döring 2008: 141]. They use different strategies of presenting themselves and expanding activities to obtain control over these places. Right-wing extremists still face the biggest difficulties in trying to exercise control over public spaces. Yet, squares, pedestrian zones, bus stops, playing fields, and swimming-pools are important spaces for extremists, because they can make themselves very visible in these places and can best demonstrate their group behaviour and draw the attention of a larger part of the population. The presence of extremists in these free spaces tends to make use of the space difficult for citizens. Parts of the German population, such as citizens with darker skin or members of the anarchist sub-culture, stay out of these spaces because they are worried about the possibility of violence. A similar view prevails among the majority of the population, who do not like the aggressive behaviour of these local 'rulers' either. Compared to other types of places, mentioned below, these are the fewest in number, but they are also the sites of the largest numbers of extremist crimes [Döring 2008: 188]. An example of one such area is the district of Prenzlauer Berg in Berline, certain parts of which foreigners and some local Germans are really afraid to visit (Die Zeit, 8 November 2007).

Döring classifies restaurants, pubs, discos, and clubs as semi-public areas, which, although they are more common, are not fully controlled by extremists because they usually do not have sufficient economic means to own these places. Most common are private places, the 'home territory' of right-wing extremism. These include the free spaces that right-wing extremists do dominate, most often shops, pubs, gardens, or clubs, owned by extremists or followers of this movement. An example is a pub in the village Heilsberg near Saalfeld in Thurungia. In April 1997 it was leased by couple of 'friends' and they quickly turned it into the hub of the local neo-Nazi scene. Other than neo-Nazis, no one else tried to go to this pub. Nor did anyone protest its existence, not even the provost or the town pastor. In the view of many inhabitants the reason was that the neo-Nazis did not misbehave or disturb public life in any way. Initially even the Thurungian Office for the Protection of the Constitutional Order. After half a year, officials ordered 
an inspection of the site and uncovered there the largest arsenal of weapons on a single site in Thurungia and they shut the pub down. Similar institutions can be found throughout Germany, and generally they are more common in the new federal states.

\section{Types of no-go-areas and support for them inside the NPD}

Although it is not the rule, we can certainly see that the NPD has influenced the formation of 'national liberated zones'. Generally, wherever the NPD is politically strong, the willingness to create fear zones is markedly higher than anywhere else. The politics of the NPD widely support such activities and the party often figures as the co-initiators of their establishment. The NPD has achieved the most success in Mecklenburg-Front Pomerania and Saxony. In some villages in these federal counties, the NPD is the third strongest political power. Their biggest success was winning $38.6 \%$ in the last communal elections in the village of Postlow. Although it may not seem so from the results of the elections to the German Bundestag, the NPD is nonetheless gaining in strength. In the last federal elections in 2005 they had a vote share of 1.6\%. Experts agree that if the NPD had cooperated more intensely in this period with neo-Nazi institutions their results would have been even higher (but not enough to enter the Bundestag) [Staud 2006: 15]. Even if they did get into Parliament, it is clear that they would be isolated there in their opinions. But in society they are definitely not in isolation - at least in the eastern part of the country. The NPD is well aware that they are more successful in economically disadvantaged regions. For this reason, during their last convention in Bamberg in the summer of 2008, they changed the strategy they use to address voters, and instead of aiming to be a party of all-round success, that is, a party that can celebrate political gains across the country, they plan to concentrate more on their most successful regions, such as those in the former East Germany, and there they hope to become a 'catch-all' party. One of the ways in which they plan to strengthen their position is by establishing 'no-go-areas', where they intend to demonstrate how they would govern in power.

Let's now look at how four theorists in the NPD party in the 1990s (when the discussions about zones were culminating) viewed the eventual establishment of these zones. I examined articles that these four party officials published in the right-wing extremist press. Each of these four theorists has their backers and opponents. The first example is Tomas Hetzer, a representative of the National Democratic Academic Unit. Hetzer addressed the unit with the words: 'with the zones we will create a counter-balance. We have to create the kind of free spaces in which we can de facto assume power and we will be able to penalise - that is, to punish - weaklings and enemies, support co-fighters, and help oppressed, excluded, and persecuted fellow citizens' (Vorderste Front 2/1991). Hetzer is interested in creating a system in which the state and its 'knaves' will occupy a secondary role in shaping people's lives. The purpose of this zone is to take control of people's fates and 
establish a separate legal order and system of values. These zones need not be just geographic; they can also be mental zones or spaces in which the neo-Nazi worldview dominates. According to Hetzer, in these zones the NPD will be able to demonstrate 'freely' and without having to ask permission from the state authorities, and the NPD's 'friends' (i.e. neo-Nazis) will be responsible for maintaining safety on the streets and will protest and agitate against asylum-seekers. The reason Hetzer gives for creating such zones is that they should be places of support for 'co-fighters, where people will measure us by our acts'. He sees the main reason for their creation as a means of securing financial independence, which will help shape the party's 'inner system and coordination between friends'.

Jürgen Distler is the second NPD representative who in Deutsche Stimme has broached the possibility of establishing 'national liberation zones'. He puts more emphasis than the others on the political dimension. According to Distler, even now, 'in the centre of Germany', there exists a 'strong sub-culture of neoNazi youth' (Deutsche Stimme 12/1999). In Distler's view, which is most certainly exaggerated, this movement is already an important socialising factor among the young generation, and in his opinion it is necessary to support it and win it over politically on the side of the NPD. While Distler exaggerates, it is true that there really are parts of East Germany where neo-Nazi sub-culture to at least some extent does fulfil a socialisation role. But it is by no means a mass phenomenon. According to Distler these nationalistically motivated youth are waging a battle on the cultural front, a battle that has arisen out of their rejection of liberal-capitalist society. Distler here refers to Antonio Gramsci and his concept of fighting for cultural hegemony. According to Distler, the only way to promote the objectives of the NPD is for the party to politically agitate and recruit young people on its side. In another words, it is necessary to replace the cultural with the political. These disillusioned youth have to be shown that the NPD represents the route to changing circumstances and systems. It is a fact that citizens of the former East Germany and the young generation in general have declining faith in democracy, something Distler demonstrates in an article in Deutsche Stimme. Drawing on surveys, for example, he argues that while in the year 1990, $41 \%$ of Germans considered democracy in Germany as the best form of government, in the year 1997 the figure was only $23 \%$. So Distler recommended supporting by peaceful means movements of the disillusioned and socially excluded by creating zones in which they can move around and fulfil themselves freely.

Jürgen Schwab is the author of the third view in the discussion of 'national liberated zones' (Deutsche Stimme 10/1999). Schwab advocates the need to create zones in which the initiators will have an 'interpretative monopoly', will themselves decide what is right and what is wrong, and will shape public opinion. Schwab's position is strongly anti-democratic, but it is nonetheless the most 'tolerant' of the four views presented here. Schwab writes that everyone who behaves 'fairly' (that means also foreigners and people with alternative views) deserves protection in the zone. In his view it is necessary to use the territory of the former East Germany, where there is evidently strong support for the NPD, to establish 
these zones. About the western parts of the country he notes: 'In the west of the country the concept of free zones is by comparison [with the eastern part of the country - author's note] more complicated. Here, the main concern should be to fight by all possible means allowed by law in order to build a solidary movement of cultural resistance.'

Steffen Hupka, another top member of the NPD, writes in his article in Deutsche Stimme what surely most neo-Nazis in Germany wish: 'A liberated zone should not be just the material base of our fight, it should also provide us with spiritual and moral sources of strength. It has to be the base of our domestic struggle. Thence we can move farther along the front, we must create more, secondary battle zones, so we have to open these liberated zones.' (Deutsche Stimme $11 / 1999)$ The point of establishing 'liberated zones' is to establish a 'national and social system of government', which means removing the democratic state system and establishing neo-Nazism.

Inside the NPD, sympathies for the above concepts vary between different factions. Hetzer and Hupka maintain the most radical positions. On the other hand, Distler emphasises the cultural dimension and argues the need to introduce a political dimension into the fight for cultural hegemony. What unites all four views is their volkisch posturing and the demand to establish neo-Nazi principles in these zones. 'National liberated zones' are nothing more than a synonym for the establishment of a dictatorship, and what this is about - regardless of whether individual authors state or write this directly or indirectly - is the transition to neo-Nazism based on racial 'purity'. That all the top NPD members agree with these visions - even if just any one of them - and aspire for their realisation puts them in sharp conflict with the German constitutional order.

German citizens living in the areas of the former East Germany need to be assured that the democracy established after 1989 is not just a Western import; that the democratic progress of their country is also in their interest [Siegler 1991]. Nowadays, in the eastern parts of Germany, especially in Saxony and Mecklenburg-Frontal Pomerania, there are big waves of protests and disillusionment with democracy (e.g. demonstrations against the Hartz IV reforms, etc.). The NPD could benefit much from this situation. More than ever before it can offer the public not just nationalistic and chauvinist invective but instead is able to understand the people's social problems and offer a solution: eliminating people's problems through the formation of an ethnically homogeneous society. Their campaign prospers because democracy does not yet have sufficiently deep roots in the new federal states.

\section{Four NPD aims in relation to no-go-areas}

First, I must say that the concept described below is the NPD's party strategy and is recommended by all its officials. It is not a process through which to create 'national liberation zones'; it is a strategy to obtain political power. Because, 
according to neo-Nazis, the zones represent one step on the way towards taking control of all of society, we should look at these principles. Shortly after Udo Voigt became the chair of the NPD, at a party convention in Stavenhagen in 1997 the party formulated its first three strategic principles: the struggle for parliament, the struggle for the streets, and the struggle for people's 'minds'. In the year 2004 the struggle for organised will was also added.

When the NPD participate in elections, they refer to this as the 'struggle for parliament'. The municipal congresses in which the NPD is represented (Saxony, Mecklenburg - Vorpommern; the NPD refers to this as the Dresden-Schwerin axis) serve mainly as public propaganda fora for their ideas. They are also important strategic places because as representation in the legislature gives this party an air of trustworthiness and secures financial resources for it [Verfassungsschutzbericht 2006: 90]. It is possible to glean from NPD documents that the party is not at all interested in constructive politics. The motivation, in addition to money, for their participation in elections is to try to prevent - or at least complicate - the eventual prosecution of the party's representatives.

The NPD considers demonstrations and other public scenes as part of the 'struggle for the streets'. This reference is borrowed from the Nazi era, when Hitler and his followers were also concerned about 'capturing the streets', that is, about obtaining control over public areas, which they succeeded in doing during the 1930s with the help of Sturmabteilung (Storm detachment or stormtrooper) units. The NPD added to this concept the idea of creating 'national liberation zones' using their own 'warriors' to maintain 'order'. For the party, demonstrations and protest actions are not only a way of promoting themselves, but also of reinforcing the sense of belonging among its members [Mikulčíková 2007]. Above all, the NPD has a clear aim: appealing to younger voters. Currently, the average age of party members is (as in the far left groups) the very inauspicious age of 65 [Milza 2005: 354] Through the 'struggle for the streets' offensive they want to try to bring into their ranks young people associated in 'familiar alliances'.

The NPD means two things by the 'struggle for people's minds': the need to engage in educational activities, and the need for the party to operate and expand its aims and ideas to the wider ranks of society. To this end the party offers occasional training sessions and prepares its activists to be able to critically counter their opponents' ideas. The party's entire intellectual guidance comes from the party's centre [Verfassungsschutzbericht 2006: 91]. The party chair, Udo Voigt, is a political scientist and he and the narrow circles of top party leadership together follow developments in society and try to react appropriately so as to gain further points among the public. Under his leadership, the party's media face has changed dramatically, its pre-election campaigns have modernised, and a greater accent has been put on communal politics. In his view, today the NPD does not have to be just a 'cadre' party, but should instead open up and present itself to society as a modern party.

The last concept is the 'struggle for organised will'. By this the NPD and especially its chair hope to provide an answer to what has so far been the biggest 
weak point of German right-wing extremism: the fractionalism of powers. The aim is to establish cooperation, create an institutional framework, and form a true 'national front' (Heimatfront). The first step in this was the signing of an agreement between the NPD and the German Common Union (DVU, Deutsche Volksunion) on mutual support between their candidates (the so-called Deutschlandpakt) [Verfassungsschutzbericht 2006: 66, 89]. This was de facto a non-aggression pact, wherein both sides divided up the territory of Germany according to the areas in which each is strongest and there they do not run against each other.

\section{Conclusion}

This article is concerned with a phenomenon that, according to the arguments of state officials, the police, and other relevant institutions, does not actually exist - no-go-areas. By contrast, the national press in Germany, various civic associations, and also experts [Milza 2005: 356] acknowledge and give examples of the existence of no-go-areas. No-go-areas in the sense in which they are understood and defined by neo-Nazis do not (yet) exist or exist exceptionally in some neo-Nazi pubs or private clubs. These are places to which people who do not share the views of the group that controls them do not have access anyway, so in the strict sense of the word they are not no-go-areas. To this day, neo-Nazis have largely not succeeded in realising their goals in full and their plans for now remain mainly just ideas. What do exist - and press articles and statements from respondents confirm this [Staud 2006: 13; Frindte and Neumann 2002] - are fear zones, places where foreigners, members of a national minority, or even just people that do not think like neo-Nazis, are scared to go.

What else could be the outcome of the formation of these zones? German democratic political parties need to understand and accept East German identity more than they have in the past. Thus far most parties have tried to diminish the specific features of the region of the former GDR and dissolve them in a republicwide outlook. The result of this has been a weakening of the trust placed in these political subjects and an increase in the number of supporters and voters of radical and extremist parties, in particular of Die Linke and the NPD. Both parties are very capable of taking advantage of the authoritarian views that exist in a large part of the former GDR region as a result of forty years of communist rule there. 'All for the good of the people' (Alles für das Wohl des Volkes) was once the main slogan of the SED (Sozialistische Einheitspartei Deutschlands), and is today presented to the public by Die Linke and the NPD in reinvented forms. This is very apparent in Saxon-Switzerland not far from the Czech border. Around 17\% of the inhabitants in the new federal states (i.e. former East Germany) earn 7.5 Euro an hour or less (in the old federal states, i.e. former West Germany, only 8\% earn that little) (Die Welt, 22 August 2008). Currently (August 2008) unemployment in the eastern part of Germany is around $12.8 \%$, while in the western part it is $6.4 \%$. These are revealing socio-economic data for regional specifics. 
The strong support for the NPD and the idea of forming 'national liberation zones' is the East German public's reaction to the (alleged) failure of politics. According to recent research, faith in democracy has been declining across all of Germany, so today even two-thirds of the inhabitants of the western states $(60 \%)$ do not have faith in democracy, but the biggest decline has been observed in the eastern part of the country (Die Welt, 21 April 2008), where only 44\% have trust in democracy. The population's frustrations connected with the transformation and from joining the western part of Germany are still very strong. The situation is even worse in the former GDR in terms of its trust in the economic system, only one in three former East Germans believes in the system and considers it the right thing (the average for Germany as a whole is $48 \%$ ). In addition, fewer East Germans believe in the existing social system - just 30\% compared to the overall German average of $40 \%$. Germany's chief objective should be to halt these trends. Torald Staud found that if we do not measure right-wing extremism according to the number of votes and mandates in elections but instead according to idea preferences, then in the eastern part of Germany support for NPD groups is as much as 30\% [Staud 2006].

Neo-Nazi no-go-areas will probably not be established any time soon in Germany. The majority of the German public and the country's politics are democratically oriented (conflict democracy - streitbare Demokratie). For all that, it is disturbing how well the neo-Nazis are able to take advantage of the democratic deficit that can be found in every society, and in the post-modern society this is doubly true. Regrettably, today they are already able to rely on certain bastions of support - the economically and socially deprived regions in the western part of Germany, and this makes the situation much more complicated.

LUKÁŠ NovOTNÝ is a political scientist and sociologist and a lecturer in the Department of Human Resources Development and the European Union of Jan Amos Komenský University in Prague and in the Department of Political Science and Philosophy at the Faculty of Arts of Jan Evangelista Purkyně University in Ústí nad Labem. His research field is political systems in German-speaking countries, Czech-German relations, and European integration with a focus on Czech policy in the EU.

\section{References}

Backes, Uwe and Eckhard Jesse. 1989. Politischer Extremismus in Deutschland. Bonn: Bundeszentrale für politische Bildung.

Bale, Jeffrey M. 2002. 'National Revolutionary Groupuscules and the Resurgence of "Left-Wing" Fascism: The Case of France's Nouvelle Résistance.' Patterns of Prejudice 3: 24-49.

Bauman, Zygmunt. 2003. Flüchtige Moderne. Frankfurt a.M.: Suhrkamp. 
Beck, Ulrich. 2004. Riziková společnost. Na cestě k jiné modernitě. (Risk Society: On the Road to Another Modernity) Prague: Sociologické nakladatelství.

Bergmann, Werner and Rainer Erb. 1994. 'Eine soziale Bewegung von rechts? Entwicklungen und Vernetzung einer rechten Szene in den neuen Bundesländern.' Forschungsjournal Neue Soziale Bewegungen 2: 80-98.

Bobbio, Norberto. 2003. Pravice a levice. Dưvod a smysl rozdělení politické scény. (Right-wing and Left-wing: The Reason and Purpose behind the Division of the Political Sphere) Brno: Centrum pro studium demokracie a kultury.

Chmelík, Jan. 2001. Extremismus a jeho právní a sociologické aspekty. (Extremism and Its Legal and Sociological Aspects) Prague: Linde.

Dietzsch, Martin and Anton Maegerle. 1996. 'Digitales Braun.' Pp. 923-932 Handbuch deutscher Rechtsextremismus, edited by Jens Mecklenburg. Berlin: Espresso.

Dietzsch, Martin and Anton Maegerle. 1997. “'Befreite Zone” Thule-Netz?' Pp. 170-192 in Das Netz des Hasses. Rassistische, rechtsextreme und neonazistische Propaganda im Internet, edited by Stiftung Dokumentationsarchiv des Österreichischen Widerstands. Vienna: Stiftung Dokumentationsarchiv des Österreichischen Widerstands.

Döring, Uta. 2008. Angstzonen. Rechtsdominierte Orte aus medialer und lokaler Perspektive. Wiesbaden: Verlag für Sozialwissenschaften.

Frindte, Wolfgang and Jörg Neumann. 2002. 'Rechtsextremismus = "Ideologie plus Gewalt" - Wie ideologisiert sind rechtsextreme Gewalttäter.' Pp. 81-98 in Fremdenfeindlichkeit in Deutschland - Psychologische Befunde und Empfehlungen, edited by Rolf van Dick and Ulrich Wagner. Berlin: BMI.

European Monitoring Centre on the European Community. 1999. Annual Report 1998. Part II. Vienna: The European Union Agency for Fundamental Rights.

Findeisen, Hans-Volkmar and Joachim Kersten. 1999. Der Kick und die Ehre. Vom Sinn jugendlicher Gewalt. Munich: Antje Kunstmann Verlag.

Gertoberens, Klaus. 2004. Die braune Gefahr in Sachsen. Dresden: Edition Sächsische Zeitung.

Geyer, Julia Isabel. 2002. Rechtsextremismus von Jugendlichen in Brandenburg. Münster: LIT.

Glyn, Ford. 1992. Fascist Europe. The Rise of Racism and Xenophobia. London/Colorado: Pluto Press.

Grumke, Thomas. 2007. 'Rechtsextremismus in Deutschland. Begriff - Ideologie - Struktur.' Pp. 18-35 in Erlebniswelt Rechtsextremismus. Menschenverachtung mit Unterhaltungswert. Hintergründe - Methoden - Praxis der Prävention, edited by Stefan Glaser and Thomas Pfeiffer. Bonn: Bundeszentrale für politische Bildung.

Hafeneger, Benno. 1995. Politik der 'extremen Rechten'. Eine empirische Untersuchung am Beispiel der hessischen Kommunalparlamente. Schalbach/Ts.: Wochenschau-Verlag.

Hellmann, Kai-Uwe and Rund Koopmans. (eds.) 1998. Paradigmen der Bewegungsforschung. Entstehung und Entwicklung von Neuen sozialen Bewegungen und Rechtsextremismus. Opladen: Leske + Budrich.

Helsing, Jan van and Horst Mahler. 2001. Die Sprache des Hasses. Rechtsextremismus und völkische Esoterik. Stuttgart: Schmetterling Verl.

Ignazi, Pierro. 2003. Extreme Right Parties in Western Europe. Oxford: Oxford University Press.

Inglehart, Ronald. 1997. Modernization and Postmodernization. Princeton, NJ: Princeton University Press.

Jaschke, Hans-Gerd. 1994. Rechtsextremismus und Fremdenfeindlichkeit. Begriffe; Positionen, Praxisfelder. Opladen: Westdeutscher Verlag.

Jaschke, Hans-Gerd and Birgit Rätsch. 2001. Nach Hitler. Radikale Rechte rüsten auf. München: Bertelsmann. 
Klärner, Andreas and Michael Kohlstruck. 2006. 'Rechtsextremismus - Thema der Öffentlichkeit und Gegenstand der Forschung.' Pp. 7-41 in Moderner Rechtsextremismus in Deutschland, edited by Andreas Klärner and Michael Kohlstruck. Hamburg: Hamburger Edition.

Mikulčíková, Adriana. 2007. 'Podoby pravicového extremizmu v SRN - Nová programatika, činnost' a stratégia nemeckej NPD.' (The Faces of Right-wing Extremism in West Germany - The New Programme, Activities, and Strategies of the German NPD) Pp. 211-220 in Radikalismus a jeho projevy v současném světě, edited by Vladimír Srb and Petra Hirtlová. Kolín: ARC - VŠPSV.

Milza, Pierre. 2005. Evropa v černých košilích. (Europe in Black Shirts) Prague: Themis.

Minkenberg, Michael and Pascal Perrineau. 2007. 'The Radical Right in the European Elections 2004.' International Political Science Review 1 (28): 7-28.

Mudde, Cas. 2000. The Ideology of the Extreme Right. Manchester/New York: Manchester University Press.

Niethammer, Lutz. 1969. Angepasster Faschismus. Politische Praxis der NPD. Frankfurt: S. Fischer.

Novotný, Lukáš. 2008a. 'Co si počít s německou NPD?' (What to Do about the German NPD) Sociozeb 4: 7-9.

Novotný, Lukáš. 2008b. 'Zlo se skrývá v každém z nás. Psychologický experiment ve filmu Náš vůdce.' (Evil Hides within Each of Us: A Psychological Experiment in the Film 'Our Führer') Dějiny a současnost 7 (30): 17-20.

Röpke, Andrea. 2004. 'Nachschub und Heimatfront.' Pp. 106-109 in Braune Kameradschaften. Die neuen Netzwerke der militanten Neonazis, edited by Andrea Röpke and Andreas Speit. Berlin: Links.

Rucht, Dieter. 2002. 'Rechtsextremismus aus der Perspektive der Bewegungsforschung.' Pp. 75-86 in Handbuch Rechtsradikalismus. Personen - Organisationen - Netzwerke. Vom Neonazismus bis in die Mitte der Gesellschaft, edited by Thomas Grumke and Bernd Wagner. Opladen: Leske + Budrich.

Scherr, Albert. 2007. 'Rechtsextremismus, die Mitte der Gesellschaft und die Grenzen zivillgesellschaftlicher Strategien.' Pp. 99-108 in Zivilgesellschaftliche Strategien gegen die extreme Rechte in Hessen, edited by Margrit Fröhlich. Frankfurt a.M.: Brandes \& Apsel Verlag.

Scheuch, Erwin K. and Hans-Dieter Klingemann. 1967. 'Theorie des Rechtsextremismus in westlichen Industriegesellschaften.' Hamburger Jahrbuch für Wirtschafts- und Gesellschaftspolitik 12: 11-29.

Sennett, Richard. 1998. The Corrosion of Character. The Personal Consequences of Work in the New Capitalism. New York: W.W. Norton \& Co.

Siegler, Bernd. 1991. Auferstanden aus Ruinen. Rechtsextremismus in der DDR. Berlin: Ed. Tiamat.

Staud, Torald. 2006. Moderne Nazis. Die neuen Rechten und der Aufstieg der NPD. Köln: Kiepenheuer \& Witsch.

Stöss, Richard 2000. Rechtsextremismus im vereinten Deutschland. Bonn: Friedrich-EbertStiftung.

Verfassungsschutzbericht. 1998. Köln: Bundesministerium des Innern.

Verfassungsschutzbericht. 2006. Berlin: Bundesministerium des Innern.

Verfassungsschutzbericht Brandenburg. 2007. Potsdam: Ministerium des Innern des Landes Brandenburg.

Verfassungsschutzbericht Sachsen. 2003. Dresden: Ministerium des Innern des Landes Sachsen.

Virchow, Fabian. 2004. 'The Groupuscularization of Neo-Nazism in Germany: The Case of the Aktionsbuero Norddeutschland.' Pattern of Prejudice 1 (38): 59-73. 
von Beyme, Klaus. 1988. 'Right-Wing Extremism in Post-War Europe.' Pp. 8-11 in Right-Wing Extremism in Western Europe, edited by Klaus von Beyme. London: Frank Cass.

Wagner, Bernd. 1994. 'Gewaltaktivitäten und "autonome" rechtsextrem-orientierte Strukturen in den neuen Bundesländern.' Pp. 77-97 in Neonazismus und rechte Subkultur, edited by Werner Bergmann and Rainer Erb. Berlin: Metropol.

Wagner, Bernd. 1998. 'National befreite Zonen? Ein Diskussionsbeitrag.' Bulletin - Schriftenreihe des Zentrums Demokratische Kultur 3: 35-37.

Wahl, Klaus. 1989. Die Modernisierungsfalle. Gesellschaft, Selbstbewusstsein und Gewalt. Frankfurt a.M.: Suhrkamp.

Walter, Jürgen W. 1994. Wer wählt rechts?: Die Wähler und Anhänger rechtsextremistischer Parteien im vereinigten Deutschland. Munich: Beck.

\section{Press sources}

Berliner Morgenpost (2006)

Deutsche Stimme (1999-2002)

Einheit und Kampf (1990)

Frankfurter Rundschau (1997)

Thule Journal (1993)

Der Spiegel (2007)

Volksstimme (2001)

Vorderste Front (1991)

Die Welt (2007-2008)

Die Zeit (1999-2007) 